Науковий вісник НлТУ України Scientific Bulletin of UNFU

https://nv.nltu.edu.ua

https://doi.org/10.36930/40310302

Article received 24.03.2021 p.

Article accepted 29.04.2021 p.

UDC 630.[524.37+525+651.71]
ISSN 1994-7836 (print)

ISSN 2519-2477 (online)

$@ \bowtie$ Correspondence author

S. V. Portakh

portakh@nltu.edu.ua

П. Г. Хомюк, Л. С. Осадчук, С. В. Портах

Національний лісотехнічний університет Украйни, м. Львів, Украӥна

\title{
СТАНОВЛЕННЯ ТА ОСОБЛИВОСТІ ЗАСТОСУВАННЯ НОРМАТИВІВ 3 ТАКСАЦІї ТОВАРНОЇ СТРУКТУРИ ЗАПАСІВ ДЕРЕВОСТАНІВ І ЗАГОТОВЛЕНИХ КРУГЛИХ ЛІСОМАТЕРІАЛІВ
}

Товарна структура запасів є важливою таксаційною характеристикою господарського значення деревостанів і враховується під час визначення суми рентної плати за спеціальне використання лісових ресурсів, як основної частки лісового доходу, обгрунтування віку головного рубання, вибору головної породи, визначення ефективності лісогосподарських заходів, економічних розрахунків з оцінки ефективності лісовирощування, оцінки раціональності розкряжування стовбурів дерев на ділові сортименти, планування постачання лісоматеріалів від заготівельників до споживачів, складання балансів виробництва та низки інших завдань. У роботі описано основні підходи до характеристики деревного запасу за розмірно-якісними категоріями, які діяли в різний час на території України від початку XX ст. і до сьогодні. Здійснений аналіз лісовпорядних інструкцій, державних стандартів та робіт науковців, виконаних на підставі польових досліджень товаризації запасу деревостанів, дає змогу зробити висновок, що найзнаковішим є використання класів добротності, якості та товарності деревостанів. Проаналізовано зміни, які відбулися у підходах до класифікації лісоматеріалів за розмірами та якістю під час переходу до нових, гармонізованих з європейськими стандартів з класифікації та обліку круглих ділових лісоматеріалів. Серед них до найвагоміших можна віднести: збільшення частки ділової деревини у запасі внаслідок зниження вимог до якості деревини; зростання обсягів заготовлених лісоматеріалів, які використовують для технологічного перероблення; запровадження чотирьох класів якості для ділової деревини та виокремлення дров'яної деревини для промислового і непромислового використання; збільшення кількості розмірно-якісних категорій під час класифікації лісоматеріалів (сім класів діаметрів замість трьох); перехід від використання діаметра колоди без кори у верхньому відрізі для визначення об'єму лісоматеріалів до серединного діаметра в корі або без кори; відмова від промислового призначення сортиментів під час їх класифікації на користь розмірно-якісних критеріїв відповідно до потреб споживчого ринку. Також простежено розвиток нормативів з оцінки товарної структури запасів деревостанів і стандартів з класифікації та обліку круглих ділових лісоматеріалів. Наведено основні чинні нормативні документи, які використовують у практиці ведення лісового господарства під час товаризації запасу.

Ключові слова: сортиментна структура; категорія крупності; категорія технічної придатності; клас якості; державний стандарт.

\section{Вступ}

Однією $з$ основних вимог щодо ведення лісового господарства України є забезпечення підвищення продуктивності та поліпшення якісного складу лісів (Стаття 64 Лісового Кодексу) [23]. Вирішення цього завдання неможливе без дослідження товарної структури панівних деревних видів, як однієї з головних ознак лісових ресурсів, що характеризує якість деревини, яка вирощується за оберт рубання та відпускається на корені. Товарність запасів деревостанів характеризується за співвідношенням ділових і дров'яних стовбурів 3 подальшим розподілом на якісні та кількісні категорії (вихід ділової деревини за категоріями крупності, класами якості, лісоматеріалами за призначенням та вихід дров і відходів у частках від запасу або в абсолютних величинах). Упродовж останніх десятиліть змінювалися підходи до якісного оцінювання запасів деревостанів шляхом їх товаризації з використанням нормативів, складених на різній теоретичній основі. Тому вкрай важливо знати, у який спосіб відбувалося удосконалення нормативів 3 оцінювання товарної структури запасів деревостанів, що дасть змогу виявити наявні недоліки та опрацювати нові підходи до оцінювання господарського значення лісостанів панівних видів дерев.

Об'єкт дослідження - вивчення товарності запасів деревостанів на території України в різний час і сьогодні.

Предмет дослідження - європейські, міждержавні

\section{Інформація про авторів:}

Хомюк Петро Григорійович, канд. с.-г. наук, доцент, кафедра лісової таксації та лісовпорядкування.

Email: khompetro@nltu.edu.ua

Осадчук Леонід Семенович, д-р с.-г. наук., професор, завідувач кафедри ботаніки, деревинознавства та недеревних ресурсів лicy. Email: losadchuk@nltu.edu.ua

Портах Степан Володимирович, асистент, кафедра лісової таксації та лісовпорядкування. Email: portakh@nltu.edu.ua

Цитування за ДСтУ: Хомюк П. Г., Осадчук Л. С., Портах С. В. Становлення та особливості застосування нормативів з таксації товарної структури запасів деревостанів і заготовлених круглих лісоматеріалів. Науковий вісник НлТУ України. 2021, т. 31, № 3. C. 14-21.

Citation APA: Khomiuk, P. H., Osadchuk, L. S., \& Portakh, S. V. (2021). History of development and features of implementation of standards on mensuration of forest merchantable wood volume and procured round timber. Scientific Bulletin of UNFU, 31(3), 1421. https://doi.org/10.36930/40310302 
та вітчизняні нормативні документи, які регламентують підходи до оцінювання товарної структури деревостанів, а також державні стандарти із класифікації та обліку круглих ділових лісоматеріалів.

Мета роботи - проаналізувати становлення основних методичних підходів до товаризації деревного запасу для виявлення змін у підходах до якісного оцінювання нагромадженої деревини та особливостей застосування наявних і нових, гармонізованих з європейськими стандартами, нормативних документів, які регламентують розподіл запасу за розмірно-якісними категоріями.

Для досягнення зазначеної мети визначено такі основні завдання дослідження: проаналізувати історію дослідження товарної структури деревостанів для виявлення основних чинників, які визначають вибір того чи іншого підходу щодо розподілу запасу на розмірноякісні категорії; порівняти державні стандарти, що діяли раніше на території України з новими, наближеними до європейських, для визначення основних змін у товаризації запасу.

Наукова новизна отриманих результатів дослідження - вперше проведено комплексний аналіз для основних нормативних документів, які визначали розподіл деревного запасу за розмірно-якісними категоріями i вихід промислових сортиментів на території України за період від початку XX ст. і до сьогодні.

Практична значущість результатів дослідження виявлено основні тенденції, які мали вирішальний вплив на формування нових нормативів 3 оцінювання товарної структури та проблем, які виникають перед працівниками лісового господарства під час оцінювання запасів деревостанів через запровадження нових державних стандартів.

Аналіз останніх досліджень та публікацій. Якісні характеристики запасів деревостанів свого часу вивчали: М. В. Третьяков - дослідження товарності деревостанів сосни та ялини $[49,50]$, В. К. Захаров - сортиментація ростучого лісу [56], М.В.Давидов - вивчення особливостей товарності вільхових лісів України [55], Д. П. Логутов, Ф. П. Моісєєнко - складання сортиментних таблиць для таксації ростучих насаджень [53], М. П. Анучін - складання сортиментних і товарних таблиць $[3,4,5]$, В. С. Моісєєв - вивчення методик щодо створення таблиць динаміки товарної структури модальних насаджень [27], I. I. Молоткова - вивчення сортиментної структури природних ялицевих насаджень Закарпаття [28], А. П. Тябера - моделювання сортиментно-сортної структури деревостанів [53], Г. С. Дзебісашвілі - створення нормативних матеріалів товарних таблиць і математичних моделей товарно-сортиментної структури деревостанів [6], К. С. Нікітін - дослідження динаміки товарності насаджень модрини сибірської та європейської, порослевих та насінних грабових насаджень, складання сортиментних таблиць основних лісотвірних видів [30, 55], А. Г. Мошкальов - вдосконалення методів таксації товарної структури, складання товарних та сортиментних таблиць, вивчення питань щодо районів їх застосування та дослідження впливу діяльності людини на товарну структуру деревостанів [29], М. П. Горошко - дослідження товарності штучних ялицевих деревостанів [40], В.П.Кичура - вивчення динаміки товарності природних ялицевих деревостанів [40], О. С. Фелів - встановлення особливостей динаміки товарної структури природних деревостанів бука [40], C. I. Цурик - вивчення якісних характеристик запасу ялицевих молодняків [51, 52] та інші.

Серед науковців, які досліджували особливості товарної та сортиментної структури насаджень з часу набуття Україною незалежності, варто виокремити роботи: А. А. Строчинського - розроблення нормативів товарної структури, сортиментних таблиць для таксації молодняків та середньовікових деревостанів, моделей розмірно-якісної структури об'єму стовбурів основних лісотвірних деревних видів [18, 19, 39, 43, 44, 45], С. М. Кашпора - складання нормативів динаміки товарної структури насаджень $[17,18,39]$, В. А. Свинчука вивчення особливостей таксаційної будови, сортиментної і товарної структури штучних соснових лісостанів західного та центрального Полісся України [46, 47], В. В. Миронюка - розроблення нормативів об'ємів та сортиментної структури стовбурів дерев забудованої частини населених пунктів $[25,26]$, Ю. А. Алесійчук побудова нормативів та моделювання товарної структури стиглих та перестиглих соснових деревостанів Полісся України $[1,2]$, О. А. Гірса - розроблення нормативів товарності перестійних соснових деревостанів рекреаційних лісів та березових деревостанів України, моделювання динаміки товарної структури деревостанів та обгрунтування віку стиглості в соснових лісах Київщини, ясеневих деревостанів та букових деревостанів в умовах Українських Карпат [9, 10, 11, 12, 13, 39], Г. Г. Гриника - вивчення впливу горизонтальної будови на товарну структуру соснових деревостанів у різних типах лісу, дослідження впливу орографічних умов на товарну структуру ялинових деревостанів [15, 16], C. I. Гайчука - дослідження розмірно-якісної та товарної структури букових лісів Українських Карпат $[7,8]$, О. М. Сошенського - розроблення нормативів для визначення запасу і розмірно-якісної структури молодняків, середньовікових та стиглих липових деревостанів $[41,42]$, О. М. Лесніка - розроблення нормативів об'єму та розмірно-якісної структури дерев гіркокаштана звичайного в зелених насадженнях м. Києва [21, 22], С. В. Портаха - дослідження товарної структури природних ялицевих лісостанів Українських Карпат [14, 15, 38] та інші.

Матеріали та методи дослідження. Визначення основних змін у товаризації запасу та виявлення проблем при переході на нові державні стандарти здійснювали на підставі аналізу перелічених вище праць, які грунтуються на польових дослідженнях розподілу запасу деревини на розмірно-якісні категорії, а також лісовпорядних інструкцій, державних стандартів та інших нормативних документів, які регламентували товаризацію запасу і вихід основних сортиментів від початку XX ст. і дотепер.

\section{Результати дослідження та їх обговорення}

Для оцінювання якісної структури деревних запасів у лісовій таксації використовували класи добротності, класи якості та класи товарності деревостанів. Класи добротності деревостанів було введено у практику лісовпорядкування інструкцією 1908 р. на території тодішньої Російської імперії. Їх визначали за сукупністю ознак, які характеризували ступінь товарної якості деревостану у певних лісорослинних умовах. 3 часом кількість ознак для встановлення класів добротності 
зростала: склад, відносна повнота і якість деревини були передбачені лісовпорядною інструкцією 1911 р.; повнота і комерційна цінність деревостану (інструкція 1914 р.); фаутність деревостану (доповнення до інструкції 1914 р.); приріст реального деревостану порівняно 3 нормальним (інструкція 1926 р.).

За наявними на той час нормативами встановлювали п'ять класів добротності, в основу визначення яких було покладено відносну повноту - чим вищим було іiі значення, тим до вищого класу добротності належав деревостан. При цьому, як додаткові критерії таксатори використовували ступінь відхилення деревостану від нормального, наявні пошкодження стовбурів, якісний стан деревини. Разом із запасом ці критерії також використовували для встановлення цінності деревостанів [37].

Часто у лісовпорядних інструкціях наводили досить неоднозначні трактування чинників зі встановлення добротності деревостанів. Внаслідок цього до нижчого класу добротності міг бути віднесений високотоварний деревостан $з$ низькою повнотою, або високоповнотний деревостан з підвищеною кількістю фаутних дерев [52].

Оскільки клас добротності частково відображав якісний стан деревостану, у 1930 р. його замінили на інший показник - клас якості. Новий показник визначали за відсотками фаутності стовбурів дерев незалежно від повноти, складу та інших ознак. Розподіл деревостанів на класи якості за фаутністю у виробничих умовах не набув широкого застосування. Причиною цього стало те, що ознаки (вади) деревини були досить різними, деякі $з$ них не піддавалися візуальному виявленню до зрубування дерева (до прикладу, внутрішня стовбурова гниль), що призводило до їх різного впливу на загальний вихід та якість сортиментів.

31938 р. для встановлення якісного стану насаджень почали використовувати новий показник - клас товарності [4]. Він характеризував відсоток виходу ділової деревини відносно загального запасу і застосовувався для характеристики тільки пристиглих, стиглих та перестиглих деревостанів. За лісовпорядною інструкцією 1938 р. для водоохоронних лісів встановлювали чотири класи товарності. Для хвойних деревних видів було прийнято такі межі відсоткового виходу кількості ділової деревини залежно від класу товарності: 1 - понад $70 \% ; 2$ - від 51 до $69 \%$; 3 - від 30 до $50 \%$; 4 - до $30 \%$. Для листяних деревних видів норми виходу ділової деревини за класами товарності були відповідно нижчими на $20 \%$.

3 часу запровадження межі градацій для класів товарності постійно змінювалися. Найпоміркованішою і найуживанішою була шкала в лісовпорядній інструкції 1986 р., де було наведено значення відсотків виходу ділової деревини і ділових стовбурів для хвойних і листяних видів. Найбільшої деталізації класи товарності набули у проєкті "Інструкції з впорядкування лісового фонду України" 1994 р., у якій наведено розподіл відсотків загалом для хвойних видів й окремо для листяних - дуба, бука, ясена, клена, граба, берези, осики, вільхи й липи.

Під час окомірної таксації визначити вихід ділової деревини досить складно, оскільки таксатор не завжди може розпізнати внутрішні вади стовбура, які істотно впливають на вихід ділових сортиментів [52]. Разом 3 тим було доведено, що вихід ділової деревини тісно корелює $з$ часткою ділових дерев, яку можна встановити або візуально, або шляхом підрахунку кількості ділових і дров'яних дерев на обліковій ділянці.

Тому, у 1955 р. М. П. Анучін запропонував поділяти деревостани на три класи товарності за співвідношенням у них ділових і дров'яних дерев. Це нововведення виявилося вдалим і його почали широко використовувати у практиці. Як наслідок, автор уклав товарні таблиці, які передбачали сортиментацію запасу за видами дерев, середнім діаметром і класом товарності у такій послідовності: $a$ ) розподіл загального запасу у частках на ділову деревину, дров'яну деревину і відходи; б) розподіл запасу ділової деревини у частках за категоріями крупності - грубу, середню і дрібну; в) розподіл запасу ділової деревини у частках за промисловими сортиментами. Обліковою одиницею для товарних таблиць є простий одновіковий деревостан.

На сьогодні в лісах України для оцінювання якості запасів деревостанів залежно від групи віку використовують такі таблиці:

- "Сортиментні таблиці для таксації молодняків і середньовікових деревостанів" (за редакцією А. А. Строчинського, 1993);

- "Сортиментні таблиці для таксації лісу на корені" (за редакцією К. Є. Нікітіна, 1984).

Дослідження товарної структури деревостану передбачає розподіл дерев під час суцільного переліку за технічною придатністю на три категорії - ділові, напівділові та дров'яні [35]. При цьому надзвичайно важливим $\epsilon$ дотримання критеріїв з візуальної оцінки товарного стану стовбура дерева для подальшого його віднесення до тієї чи іншої категорії [35]. Особливістю оцінки товарної якості дерева під час переліку є візуальне зіставлення нижньої половини стовбура 3 наявною класифікацією ділових сортиментів за довжиною: довгомірні понад 6,5 м (ділові стовбури); середньої довжини - від 2 до 6,5 м (напівділові стовбури); короткомірні - до 2 м (дров'яні стовбури).

Під час прийняття рішення про розподіл дерев на якісні категорії важливим було врахування того, що таксаційні ознаки окремого дерева, які впливають на сортиментну структуру запасу всього деревостану, мають кількісне вираження, а якісна оцінка технічної придатності дерева виконується візуально і має вирішальний вплив на вихід сортиментів.

Зважаючи на це, таксатор, поряд із знаннями про таксаційні ознаки окремого стовбура, має володіти практичними навиками 3 розподілу стовбура на ділові сортименти відповідно до чинних стандартів на лісову продукцію, а також вмінням розпізнавати у дерев, що ростуть, ознаки деревини та їх вплив на вихід сортиментів [20].

Сортиментні та товарні таблиці передбачають загальний розподіл стовбурної деревини на такі категорії: ділова деревина, що обліковується без кори; дров'яна деревина, що обліковується 3 корою; відходи, до яких належать: кора від ділової деревини, верхівка дерева, тирса від розпилювання стовбура на сортименти тощо. Ділову деревину додатково поділяють на окремі категорії або класи за розмірами, якістю та цільовим призначенням.

Під час товаризації запасу ділову деревину за товщиною прийнято поділяти на три основні категорії крупності: грубу, середню і дрібну. При цьому згідно 3 чинними нормативами до грубої деревини всіх лісових 
видів належать відрізки стовбура (у верхньому перерізі без кори) діаметром від 25 см і більше, до середньоїдіаметром від 13 до 24 см, до дрібної- діаметром від 3 до 12 см (Податковий Кодекс України. Розділ IX. Стаття 256. Пункт 256.9) [48].

Треба зазначити, що різні автори в різний час виділяли подібні категорії крупності, проте шкала градації в них дещо відрізнялася $[3,5,20]$. Також у межах окремих категорій крупності у деяких наукових працях i таксаційних довідниках міститься розподіл ділової деревини на окремі класи товщини $[20,29,39,50]$. Так, наприклад, М. В. Третьяков [50] поділяв ділову деревину за якістю на чотири сорти, кожен з яких включав різні класи товщини за діаметром у верхньому відрізі без кори, Ф. П. Моїсєєнко [24] пропонував використовувати чотири класи товщини.

Окрім розмірних вимог, лісоматеріали мають відповідати ще й певним якісним вимогам, що відображалося поділом їх на окремі сорти. Сортність лісоматеріалів залежала від вад (фаутів) деревини і ступеня їх розвитку. У перших нормативах з товарної оцінки запасів лісоматеріали за якістю деревини та наявністю різних вад поділяли на такі категорії [54 цит. за 51]:

1-й сорт - сортименти високої якості, які заготовлювали з прикореневої частини стовбура та призначалися для виробництва спеціальної високоякісної продукції. Більшість вад у першому сорті не допускалися (пасинок, трухлява гнилизна тощо) або значно обмежувалися (грибкові ядрові плями і смуги, тріщини, нахил волокон і т. ін.);

2-й сорт - використовували для виробництва пиломатеріалів, заготовок, целюлози, деревної маси та в круглому вигляді, могли мати деякі вади (сучки, гнилі тощо), ступінь розвитку яких був дещо більший, ніж у лісоматеріалів першого сорту;

3-й сорт - допускалася заболонева гниль у хвойних і ядрових листяних деревних видах, червоточини;

безсортні лісоматеріали мали деякі ознаки деревини (заболоневі грибні забарвлення, заруби, пропили, прорості), які допускалися без обмежень або з незначними обмеженнями, наприклад, сучки.

Деревину гіршої якості відносили до дров'яної.

Кардинально новий підхід до оцінювання якості лісоматеріалів було запроваджено 3 набуттям чинності нових державних стандартів, гармонізованих 3 європейськими (початок 2019 р.). Нижче перелічені основні особливості європейської системи стандартизації круглих лісоматеріалів:

- запровадження класів (D0-D6) та підкласів ("a" та "b") діаметрів (D0 (до 10 см); D1a (10-14 см); D1b (15-19 см); D2a (20-24 см); D2b (25-29 см), D3a (30-34 см), D3b (35-39 см), D4 (40-49 см), D5 (50-59 см), D6 (60 см і більше));

- клас діаметрів визначається за серединним діаметром в корі (R) чи без кори (D) (встановлюється контрактом зі споживачем);

- за довжиною лісоматеріали поділяють на чотири класи (L1 - до 3 м включно, L2 - від 3 до 6 м включно, L3 - від 6 до 13,5 м включно, L4 - понад 13,5 м);

- класифікація круглих лісоматеріалів грунтується не на призначенні сортиментів, а на підставі розмірів та якості колод (визначається вмістом та розмірами вад деревини);

- лісоматеріали поділяють на 4 класи якості (A, B, C, D), для окремих видів (вільха, береза, осика, липа, граб, акація, вишня, черешня та ін.) - 3 класи якості (А, В, С):

- клас якості А містить лісоматеріали найвищої якості, які заготовляють переважно з нижньої частини колоди, що має чисту деревину та незначні вади, які не обмежують ії використання;

- клас якості В містить лісоматеріали середні за якістю, особливих вимог до чистоти деревини немає, наявність сучків допускається в межах середнього значення для кожного деревного виду;

- клас якості С містить лісоматеріали нижчі за якістю за середню, допускаються вади, які незначно знижують природні властивості деревини;

- клас якості D містить лісоматеріали, які не потрапили у перші три класи якості, але їх якість дає змогу виготовити 3 них пиломатеріали (40 \% об'єму деревини придатні до використання у лісопилянні, можуть заготовляти навіть зі сухостійних дерев);

- лісоматеріали, які не задовольняють вимоги чотирьох класів якості, класифікуються як деревина дров'яна промислового i непромислового використання:

- дров'яна деревина для промислового використання, завдовжки 2-4 м (призначена для промислового використання у виробництві теплової електроенергії, трісок, стружок, піролізу, гідролізу, а також як сировина для деревних плит);

- дров'яна деревина для непромислового використання, завдовжки до 2 м (реалізується у ролі палива в таких побутових пристроях, як печі, каміни і системи центрального опалення).

Загалом варто зазначити, що нові класи якості перекликаються 3 попереднім поділом лісоматеріалів за сортами. Відхід від промислового призначення сортиментів, на нашу думку, є покращенням, оскільки потреби промисловості є мінливими, а розмірно-якісна градація є більш конкретним показником і їі можна адаптовувати під новий попит на сортименти. Тим більше, що застосування товарних i сортиментних таблиць узгоджувалося 3 плановою економікою, що вимагає оцінювання якості лісових ресурсів для можливості планування ведення лісового господарства.

Аналіз споживання деревини за ХХ ст. як на території колишнього СРСР так і за кордоном, який здійснили провідні вчені $[5,29]$, виявив такі тенденції у зміні товарної структури:

- зниження мінімального діаметра заготовлених круглих лісоматеріалів;

- зниження вимог щодо наявності вад у діловій деревині (внаслідок чого зріс вихід ділових сортиментів);

- збільшення обсягів використання деревини листяних видів;

- зростання виходу балансів, фанерного кряжу та зниження частки сортиментів, які використовуються у круглому вигляді;

- збільшення обсягів заготівлі сировини для технологічної переробки;

- зростання попиту на високоякісну деревину, незважаючи на збільшення частки оброблених лісоматеріалів;

- зростання частки ділової деревини у загальному запасі.

На нашу думку, ці тенденції пояснюють зміною структури ринку споживання деревини, розвитком й удосконаленням деревообробного обладнання та загальним станом лісового фонду.

Як бачимо з наведених вище даних, класифікація ділової деревини є досить складною. В окремих науковців виникало питання наскільки доцільно характеризувати ділову деревину за такою великою кількістю показників (категорії крупності, класи товщини, сорти i т.ін.). 3 огляду на це, А. Г. Мошкальов разом 3 колективом науковців [29] для умов Ленінградської області виконав розрахунок витрат на перевезення лісоматеріалів від заготівельників до споживачів і витрат на переробку деревини при чотирьох варіантах характеристики ділової деревини.

Результати досліджень засвідчили, що чим детальніша характеристика сировини, тим більша собівартість 
транспортування, менша собівартість перероблення i нижча загальна сума собівартості. Тому характеристика ділової деревини як за категоріями крупності, так і за сортами була економічно вигідною.

Окремим напрямом товаризації деревних ресурсів $\epsilon$ розподіл ділової деревини за розмірно-якісними категоріями, який регламентується державними стандартами.

Перші стандарти на круглі лісоматеріали було запроваджено у $30-\mathrm{x}$ роках XX століття. На той час діяло понад 30 стандартів. Деревину основних сортиментів поділяли також за сортами. Відповідно, у таблицях вказували вихід сортиментів за сортами, а М. В. Третьяков та інші автори почали називати таблиці "сортиментно-сортними" [29]. Така тенденція у характеристиці ділової деревини за сортиментами і сортами зберігалася понад 30 років. Проте велика різноманітність стандартів ускладнювала роботу лісозаготівельників, оскільки перелік сортиментів і вимоги до них були досить складними.

Через це у 1967 р. запроваджено два принципово нових стандарти - ГОСТ 9462-60 та ГОСТ 9463-60 на круглі лісоматеріали замість великої кількості стандартів, які діяли раніше. У цих нормативних документах ділову деревину поділяли за категоріями крупності і сортами. На підставі цих ГОСТів у різних районах було складено низку нових сортиментних таблиць [29].

Так, у середині 70-х років введено в дію новий стандарт для круглих лісоматеріалів під назвою ГОСТ 2292 74 та ОСТ 13-55-76 на сировину для технологічної переробки (технологічні дров $a$ ). Також з 1977 р. почав діяти ГОСТ 2708-75 на заміну ГОСТ $2708-44$, у якому наведені масові таблиці об'ємів ділових сортиментів за діаметром без кори у верхньому відрізі та довжиною.

У 1990 р. ГОСТ 2292-74 замінено ГОСТом 2292-88, ГОСТом 9462-88 (для листяних деревних видів) та ГОСТом 9463-88 (для хвойних деревних видів). Треба зазначити, що після 1967 р. усі наступні ГОСТи передбачали поділ деревини за категоріями крупності та сортами.

До 1991 р. основними принципами, які визначали створення нових стандартів, були потреби виробництва у деревині. 3 часу набуття Україною незалежності, лісове господарство отримало у спадок радянські стандарти, якими послуговувалися досить довго. Проте вихід української лісопродукції на європейський та світовий ринки зумовив необхідність розроблення нових нормативних документів, які були б сумісними з вимогами до лісоматеріалів за кордоном.

31 січня 2003 р. почалося поступове узгодження українських стандартів з основними вимогами до лісоматеріалів на європейському ринку, зокрема набули чинності [33]: ДСТУ EN 1315-1-2001 "Класифікація за розмірами. Частина 1. Лісоматеріали круглі листяні" (EN 1315-1:1997, IDT); ДСТУ EN 1315-2-2001 "Класифікація за розмірами. Частина 2. Круглі лісоматеріали хвойних порід" (EN 1315-2:1997, IDT); ДСТУ EN 13091-2001 "Лісоматеріали круглі та пиляні. Метод вимірювання параметрів" та ДСТУ ЕN 1311-2001 "Лісоматеріалі круглі та пиляні. Методи вимірювання біологічних пошкоджень".

ДСТУ EN 1315-1-2001 був ідентичним перекладом EN 1315-1:1997 "Dimensional classification-Part 1: Hardwood round timber" і встановлював загальну класифікацію за розмірами зрубаних листяних лісоматеріалів та визначав їх позначення. За цим стандартом лісоматеріали круглі листяні класифікували за серединним ді- аметром колод з корою $(R)$ або без кори $(D)$. Якщо колоди класифікували 3 корою, то продавець мав зазначити відповідну поправку, яка давала б змогу не враховувати об'єм кори. Формулу для визначення цієї поправки було вказано у стандарті.

ДСТУ $E N$ 1315-2-2001 був ідентичним перекладом EN 1315-2:1997 "Dimensional classification-Part 2: Softwood round timber". Стандарт встановлював загальну класифікацію за розмірами для круглих лісоматеріалів хвойних деревних видів, яка не була пов'язана зі сферою їх застосування. Його введено замість ГОСТу 9462-88 (у частині пункту 1.2, який технічно застарів і не відповідав європейським вимогам). Згідно 3 цим стандартом, в основу класів розмірів для круглої деревини покладено діаметр під корою, вимірювання якого проводили згідно з pr EN 1309.2.1994. Поділ на класи проводили за наведеними в ДСТУ двома таблицями: класифікація за серединним діаметром; класифікація за довжиною.

31 січня 2007 р. було введено ще сім нових державних стандартів, частина 3 яких вже втратила свою дію через їх заміну [36]:

- ДСТУ EN 1310:2005 "Лісоматеріали круглі та пиляні. Метод вимірювання параметрів";

- ДСТУ EN 1316-1:2005 "Лісоматеріали круглі листяних порід. Класифікація за якістю. Частина 1. Дуб і бук";

- ДСТУ EN 1316-2:2005 "Лісоматеріали круглі листяних порід. Класифікація за якістю. Частина 2. Тополя";

- ДСТУ EN 1316-3:2005 "Лісоматеріали круглі листяних порід. Класифікація за якістю. Частина 3. Ясен, клен та явір";

- ДСТУ EN 1927-1:2005 "Лісоматеріали круглі хвойних порід. Класифікація за якістю. Частина 1. Ялина та ялиця";

- ДСТУ EN 1927-2:2005 "Лісоматеріали круглі хвойних порід. Класифікація за якістю. Частина 2. Сосна";

- ДСТУ EN 1927-3:2005 "Лісоматеріали круглі хвойних порід. Класифікація за якістю. Частина 3. Модрина та тис".

Для виконання Програми діяльності Кабінету Міністрів України, затвердженої постановою Кабінету Міністрів України № 695 від 09.12.2014р., Державне підприємство "Український науково-дослідний і навчальний центр проблем стандартизації, сертифікації та якості" (ДП "УкрНДНЦ") поступово скасувало усі чинні в Україні міждержавні стандарти (ГОСТ), що розроблені до 1992 р. [31]. Це пов'язано з тим, що в національне законодавство України, як держави-члена Світової організації торгівлі (СОТ), імплементовано положення Угоди СОТ про технічні бар'єри в торгівлі, зокрема Кодексу доброчинної практики з розроблення, прийняття та застосування стандартів, та впроваджено міжнародні і європейські принципи стандартизації.

Тому на заміну ГОСТу 2708-75 для таксації об'ємів круглих ділових лісоматеріалів було введено в дію ДСТУ 8416:2015 "Лісоматеріали круглі. Таблиці об'ємів" (розробники: працівники кафедри лісової таксації та лісовпорядкування НЛТУ України М. П. Горошко, М. М. Бусько, І. С. Ільків, П. Г. Хомюк), у якому на підставі обліку ділових сортиментів найпоширеніших лісових деревних видів створено таблицю об'ємів круглих ділових лісоматеріалів, які можна було визначити за діаметром у верхньому відрізі без кори і довжиною колоди 3 точністю до $0,0001 \mathrm{~m}^{3}$. Цей стандарт було скасовано 14.05.2019 р. наказом № 122 ДП "УкрНДНЦ" через перехід на європейські стандарти.

Для полегшення переходу на європейську систему стандартизації було запроваджено коригувальну форму на класифікацію лісоматеріалів, яка діяла до кінця 
2018 року. За цією формою передбачалося встановлення тимчасового співвідношення між сортиментами за чинними попередніми стандартами та європейськими класами якості.

А 31 січня 2019 р., у зв'язку з повним переходом на європейські стандарти, запроваджено нові нормативні документи для класифікації лісоматеріалів круглих за якістю [34]:

- ДСТУ EN 1316-1:2018 "Лісоматеріали круглі листяні. Класифікація за якістю. Частина 1. Дуб та бук" (EN 13161:2012, IDT) (на заміну ДСТУ EN 1316-1:2005);

- ДСТУ ЕN 1316-2:2018 "Лісоматеріали круглі листяні. Класифікація за якістю. Частина 2. Тополя" (EN 1316-2:2012, IDT) (на заміну ДСТУ EN 1316-2:2005);

- ДСТУ EN 1927-1:2018 "Лісоматеріали круглі хвойні. Класифікація за якістю. Частина 1. Ялина та ялиця" (EN $1927-$ 1:2008, IDT) (на заміну ДСТУ EN 1927-1:2005);

- ДСТУ EN 1927-2:2018 "Лісоматеріали круглі хвойні. Класифікація за якістю. Частина 2. Сосна" (EN 1927-2:2008, IDT) (на заміну ДСТУ EN 1927-2:2005);

- ДСТУ ЕN 1927-3:2018 "Лісоматеріали круглі хвойні. Класифікація за якістю. Частина 3. Модрина та псевдотсуга Мензіса (дугласія тисолиста, псевдотсуга тисолиста)" (EN 1927 3:2008, IDТ) (на заміну ДСТУ EN 1927-3:2005).

Український шлях застосування європейських стандартів $є$ динамічним і вже 31 січня 2021 року набувають чинності такі стандарти [32]:

- ДСТУ ЕN 1316-1:2019 (EN 1316-1:2012, IDT) "Лісоматеріали круглі листяні. Класифікація за якістю. Частина 1. Дуб та бук" (на заміну ДСТУ EN 1316-1:2018 (EN 1316-1:2012, IDT);

- ДСТУ ЕN 1927-1:2019 (EN 1927-1:2008, IDT) "Лісоматеріали круглі хвойні. Класифікація за якістю. Частина 1. Ялина та ялиця" (на заміну ДСТУ ЕN 1927-1:2018 (EN 1927$1: 2008$, IDT);

• ДСТУ ЕN 1927-2:2019 (EN 1927-2:2008; АС:2009, IDT) "Лісоматеріали круглі хвойні. Класифікація за якістю. Частина 2. Сосна" (на заміну ДСТУ ЕN 1927-2:2018 (EN 19272:2008, IDT)

Варто зазначити, що вказані стандарти на лісоматеріали не охоплюють класифікацію деревини для таких видів, як ясен, клен, в'яз, береза, вільха, осика, липа, граб, акація, вишня, черешня та інших листяних видів. У європейських країнах класифікацію для такої деревини визначають за найбільш наближеним стандартом, наприклад, якість сортиментів з вільхи або осики визначають за нормативами на тополю. В Україні лісоматеріали цих деревних видів заготовляють у чималій кількості, тому в разі застосування такої класифікації можуть виникнути багато суперечливих питань. Отож, після численних консультацій із експертами та виробниками було ухвалено рішення про розробку додаткових Технічних умов України, які встановлюють вимоги до класифікації тих видів лісопродукції, що не регламентуються європейською класифікацією. Це такі нормативні документи, як ТУУ-00994207-002:2018 "Лісоматеріали круглі листяних порід. Класифікація за якістю" та ТУУ-00994207-003:2018 "Лісоматеріали круглі хвойних та листяних порід. Правила класифікації". Також було прийнято інші Технічні умови України, які регламентують способи вимірювання візуальних характеристик деревини та їх класифікацію - ТУУ-00994207001:2018, маркування, сортування, транспортування, приймання, облік та зберігання круглих лісоматеріалів - ТУУ-00994207-004:2018 та класифікацію, облік, технічні вимоги до деревини дров'яної- ТУУ00994207-005:2018.
Загалом на сьогодні для класифікації та вимірювання круглих ділових лісоматеріалів лісогосподарські підприємства України використовують 30 нових державних стандартів та технічних умов. Їх застосування дає змогу уніфікувати класифікацію та облік круглих ділових лісоматеріалів, привести у відповідність з європейськими стандартами вимоги щодо якості деревини та підходи до визначення об'ємів сортиментів.

\section{Висновки}

Питання розроблення методичних підходів до обліку деревних ресурсів завжди були досить складними 3 огляду на значну кількість чинників, що впливають на кінцевий вихід сортиментів. Аналіз нормативів 3 товаризації запасу виявив, що до таких можна віднести: природні особливості деревостанів, лісорослинні умови, склад деревостану, вік, біоекологічні особливості деревного виду, фаутність. Останнім часом більш вагомими стають господарські заходи 3 формування та оздоровлення лісів, що позначається на нормативних документах, у яких виписано підходи до класифікації і таксації круглих лісоматеріалів.

Характерною особливістю нормативів з класифікації та вимірювання лісопродукції, які діяли до 2019 р. на території України, було врахування взаємозв'язків між основними таксаційними показниками деревостанів і закономірностями їх формування 3 часом. На цій теоретичній основі за допомогою різних наукових підходів для окремих деревних видів було створено переважну більшість сортиментних і товарних таблиць, державних стандартів $з$ вимогами до розмірів сортиментів та ін.

На сьогодні кон'юнктура ринку диктує потребу у лісоматеріалах різних розмірів, які відповідають певним вимогам, створюючи цим самим попит і пропозицію. Тому перехід до оцінювання вирощеної деревини за розмірно-якісними ознаками $є$ простіший і більш економічно виправданий.

Виконаний аналіз вітчизняних і зарубіжних нормативів засвідчив, що до основних тенденцій, які мали вирішальний вплив на формування нових нормативів 3 оцінювання товарної структури, можна віднести: збільшення частки ділової деревини у запасі внаслідок зниження вимог до якості деревини; зростання об'ємів лісоматеріалів, що використовуються для технологічної переробки; збільшення кількості розмірних категорій під час класифікації лісоматеріалів; перехід від використання діаметра колоди без кори у верхньому відрізі для визначення об'єму лісоматеріалів до серединного діаметра в корі або без кори.

Передумовою застосування сучасних нормативів була відмова від промислового призначення сортиментів під час їх класифікації на користь розмірно-якісних критеріїв відповідно до потреб споживчого ринку.

Аналіз нових, гармонізованих 3 європейськими, стандартів виявив, що перед працівниками лісового господарства постали нові проблеми, які потребують негайного вирішення, зокрема: підвищення точності таксації об'ємів сортиментів шляхом використання нормативів, побудованих на підставі серединного діаметра без кори; покращення сортиментної структури ліквідного запасу для можливості заготівлі більшої кількості круглих лісоматеріалів класу якості А; уніфікація нормативної бази 3 оцінювання деревостанів лісосічного фонду; використання єдиних таблиць об'ємів сортиментів під час електронного обліку деревини; виконання 
сортиментації запасів за чинними стандартами і технічними умовами та ін.

Зміна кліматичних показників, які впливають на перебіг росту основних деревних порід, призводить до формування деревостанів різної товарності в окремих лісорослинних зонах, які узгоджуються з прийнятим фізико-географічним районуванням території. 3 огляду на це, важливими залишаються регіональні дослідження товарної структури запасів деревостанів панівних деревних видів, а також удосконалення підходів до визначення об'ємів сортиментів, зокрема, шляхом використання твірної стовбура, що дасть змогу автоматизувати обчислення за умови виконання достатньої кількості вимірювань.

Ведення господарства в експлуатаційних лісах різних форм власності призводить до зниження відносної повноти, а отже, і зменшення повнодеревності деяких стовбурів, збільшення протяжності крони дерева відносно його висоти, що $є$ причиною істотних відхилень під час таксації товарності за наявними загальними таблицями. Тому застосування регіональних сортиментних і товарних таблиць 3 урахуванням інтенсивності господарських заходів дасть змогу виявити фактичну товарну структуру запасів деревостанів і точніше оцінити якість деревини на корені.

\section{References}

1. Aleksiychuk, Yu. A. (2005). Modeli tovarnoi strukturi stiglih ta perestiynih sosnovih nasadzhen Polissia Ukraini. Agrarna nauka $i$ osvita, 6(5/6), 122-125. [In Ukrainian].

2. Aleksiychuk, Yu. A. (2005). Patterns of diameter distribution as basis for creating normative materials of merchantable volume structure of mature and over mature pine forests. Agrarna nauka $i$ osvita, 6(1/2), 112-117. [In Ukrainian].

3. Anuchin, M. P. (1981). Assortment and merchantable volume tables. Moscow: Lesnaya promyshlennost, 535 p. [In Russian].

4. Anuchin, M. P. (1982). Forest mensuration. Moscow: Lesnaya promyshlennost, $552 \mathrm{p}$. [In Russian].

5. Anuchin, M. P., Moshkalev, A. G., Fedosimov, A. N., Anisochkin, V. G., \& Davidov, G. M. (1981). On the improvement of assortment and merchantable volume tables. Lesnoe hoziaystvo, 11, 41-45. [In Russian].

6. Dzebisashvili, G. S. (1985). Merchantable volume structure tables and equations for predicting the wood product assortment structure of the forests. Tbilisi, $96 \mathrm{p}$. [In Russian].

7. Gaychuk, S. I., \& Girs, O. A. (2012). Size-qualitative structure of beech tree stems in over mature forests of Ukrainian Carpathians. Scientific reports of the NUBiP of Ukraine, 255, 27-36. [In Ukrainian].

8. Gaychuk, S. I., \& Girs, O. A. (2016). Comparison and accuracy evaluation of normative materials for beech trees and forests of different age, size-qualitative and merchantable volume structure in Ukrainian Carpathians. Scientific reports of the NUBiP of Ukraine, 255, 27-36. [In Ukrainian].

9. Girs, O. A. (1999). Normative materials of merchantable volume structure of birch forests of Ukraine. Scientific herald of the National Agrarian University, 17, 327-329. [In Ukrainian].

10. Girs, O. A. (2000). Normative materials of merchantable volume structure of optimal pine forests. Scientific herald of the National Agrarian University, 27, 324-332. [In Ukrainian].

11. Girs, O. A. (2004). Justification of major cutting age of beech forests in conditions of Carpathians. Scientific herald of the National Agrarian University, 71, 148-155. [In Ukrainian].

12. Girs, O. A. (2008). Normative materials of dynamics of merchantable volume structure of ash forests and justification of major cutting age in ash exploitational forests. Scientific herald of the National Agrarian University, 126, 271-276. [In Ukrainian].
13. Girs, O. A., \& Kirichok, L. S. (2010). Normative materials of dynamics of merchantable volume structure of spruce forests. Scientific Bulletin of UNFU, 20(13), 142-147. [In Ukrainian].

14. Goroshko, M. P., \& Portakh, S. V. (2010). Age-related changes in the distribution of trees by the categories of technical suitability in the modal fir forests of Gorgans (Ukrainian Carpathians). Scientific Bulletin of UNFU, 20(10), 8-12. [In Ukrainian].

15. Goroshko, M. P., Hrynyk, H. H., \& Portakh, S. V. (2011). Correlation between merchantable volume structure and horizontal composition of fir forests of Ukrainian Carpathians. Scientific Bulletin of UNFU, 20(17), 27-34. [In Ukrainian].

16. Hrynyk, H. H., Gromyak, O. Yu., Shishkin, A. V., \& Moseychuk, P. P. (2014). The influence of the horizontal structure on the merchantable volume structure of scotch pine forests in the different types of the forests. Scientific Bulletin of UNFU, 24(7), 14 25. [In Ukrainian].

17. Kashpor, S. M. (1999). Methodological basis for developing standards of dynamics of forests merchantable volume structure. Scientific herald of the National Agrarian University. Series: Forestry, 17, 265-268. [In Ukrainian].

18. Kashpor, S. M., \& Strochinsky, A. A. (Eds.). (2013). Reference book for forest mensuration. Kyiv: Vidavnichiy dim "Vinichenko", 496 p. [In Ukrainian].

19. Khomiuk, P. H. (1993). Assortment tables for mensuration of young and middle-aged forests. Kyiv: USHA, 460 p. [In Russian].

20. Kozlowsky, V. B. (1965). Methodological instructions for creating sample plots, selecting model trees and compiling volume tables. Moscow: CNIITEI, 87 p. [In Russian].

21. Lesnik, O. M. (2017). The features of size-qualitative structure of chestnut trees in green plantings of Kyiv city. Scientific Bulletin of UNFU, 27(4), 48-51. https://doi.org/10.15421/40270410

22. Lesnik, O. M., \& Girs, O. A. (2017). Comparison of developed volume and size-qualitative structure standards for chestnut trees in green plantings of Kyiv city with existing analogues. Scientific $\begin{array}{lll}\text { Bulletin of UNFU, 27(5), 34-37. } & \text {. }\end{array}$ https://doi.org/10.15421/40270506

23. Lisoviy kodex Ukraini (redaktsiya vid 07.11.2020) [Tax code of Ukraine. (Date of application: 07.11.2020). Retrieved from: https://zakon.rada.gov.ua/laws/show/3852-12\#Text. Ukrainian].

24. Logutov, D. P., \& Moyseenko, F. P. (1959). Assortment tables for the mensuration of standing forests. Kiev: Gosstroyizdat USSR, 686 p. [In Russian].

25. Mironyuk, V. V. (2006). The features of size-qualitative structure of the tree stems of green plantings of Kyiv city. Agrarna nauka $i$ osvita, 7(5/6), 93-97. [In Ukrainian].

26. Mironyuk, V. V. (2006). Volume and assortment structure regulations of maple trees in urban built part of Kyiv city. Agrarna nauka i osvita, 7(3/4), 108-113. [In Ukrainian].

27. Moiseev, V. S., Moshkalev, A. G., \& Nahabtsev, I. A. (1968). Method of compiling of yield tables and tables of dynamics of merchantable volume structure of modal forests. Leningrad: LTA, 88 p. [In Russian].

28. Molotkova, I. I. (1965). The structure, biology and assortment structure of natural fir forests of Transcarpatia: abstract of the dissertation for the degree of a candidate of agricultural sciences. Kharkov, 23 p. [In Russian].

29. Moshkalev, A. G., Knize, A. A., Ksenofontov, N. I., \& Ulanov, N. (1982). Mensuration of forest merchantable volume structure. Moscow: Lesnaya promyshlennost, 160 p. [In Russian].

30. Nikitin, K. E. (1984). Tables for forest mensuration. Kyiv: Urozhay, 630 p. [In Russian].

31. Order of December 14, 2015 № 184. On cancellation of interstate standards in Ukraine, developed by 1992. Retrieved from: https://zakon.rada.gov.ua/rada/show/v0184774-15\#Text. [In Ukrainian].

32. Order of December 26, 2019 № 500. On implementation and cancellation of national standards, cancellation the amendment to the national standard. Retrieved from: https://zakon.rada.gov.ua/rada/show/v0500774-19\#Text. [In Ukrainian]. 
33. Order of December 28, 2001 № 657. On approving of national standards of Ukraine. Retrieved from: https://zakon.rada.gov.ua/rada/show/v0657565-01\#Text. [In Ukrainian].

34. Order of December 4, 2018 № 460. On implementation and cancellation of national standards, implementation the changes to the national standard, cancellation changes and amendments to the national standards. Retrieved from: https://zakononline.com.ua/documents/show/56896 56896. [In Ukrainian].

35. Order of January 21, 2013 № 9. On approval of instructions on demarcation and mensuration of cutting areas, releasing logging tickets and inspection of timber harvesting sites in the forests of the State Forest Resources Agency of Ukraine. Retrieved from: https://zakon.rada.gov.ua/rada/show/v0009820-13\#Text.

[In Ukrainian].

36. Order of September 2, 2005 № 239. On approving of national standards of Ukraine and cancellation of regulatory documents. Retrieved from: http:/www.leonorm.lviv.ua/p/NL DOC/UA/200501/Nak 239.htm. [In Ukrainian].

37. Orlov, M. M. (1929). Forest mensuration. Leningrad: Izd. Jurn. Lesnoe hozyaistvo i lesnaya promishlennost, 250 p. [In Russian].

38. Portakh, S. V., Horoshko, M. P., \& Havryliuk, V. V. (2019). Predicting under-bark diameter on different height of the tree stems of white fir in the Ukrainian Carpathians, Scientific Bulletin of UNFU, 29(5), 56-59. [In Ukrainian]. https://doi.org/10.15421/40290511

39. Portakh, S. V. (1987). Regulatory and reference materials for mensuration of forests of Ukraine and Moldova. Kiev: Urozhai, 560 p. [In Russian].

40. Saban, Ya. A., Horoshko, M. P., Kichura, V. P., Feliv, A. A., Chorny, O. S., \& Kucheryavy, V. A. (1977). The structure, growth and dynamics of the merchantable volume structure of main forest tree species by types of forests and with forest zoning. methodological recommendations for forest management on typological basis. Lvov: LLTI, 104 p. [In Russian].

41. Soshensky, O. M. (2015). Creating the normative materials for estimation the growing stock volume and size-qualitative structure of mature linden forests. Scientific Bulletin of UNFU, 25(9), 8289. [In Ukrainian].

42. Soshensky, O. M. (2015). The size-qualitative structure of the linden tree stems in young and middle-aged forests. Scientific reports of the NUBiP of Ukraine, 229, 31-38. [In Ukrainian].
43. Strochinsky, A. A., \& Kashpor, S. M. (2007). Merchantable volume structure of the main forest tree species. Kyiv: NAU, 25 p. [In Ukrainian].

44. Strochinsky, A. A., \& Lakida, P. I. (1990). Normative materials for estimation of growing stock volume and the assortment structure of the artificial pine forests. Lisove gospodarstvo, lisova, paperova i derevoobrobna promislovist, 1, 16-19. [In Ukrainian].

45. Strochinsky, A. A., Kashpor, S. M., \& Polyakov, O. V. (2007). Models of the volume size-qualitative structure of the stems of main forest tree species. Kyiv: NAU, 14 p. [In Ukrainian].

46. Svinchuk, V. A., \& Strochinsky, A. A. (2006). The merchantable volume structure of the artificial pine forests in Western and Central Polissya of Ukraine. Agrarna nauka i osvita, 7(1/2), 7377. [In Ukrainian].

47. Svinchuk, V. A., \& Strochinsky, A. A. (2007). The size-qualitative structure of the growing stock volume of young and middleaged pine forests in Western and Central Polissya of Ukraine. Scientific herald of the National Agrarian University, 106, 135143. [In Ukrainian].

48. Tax code of Ukraine. (Date of application: 07.11.2020). Retrieved from: https://zakon.rada.gov.ua/laws/show/2755-17\#Text. [In Ukrainian].

49. Tretyakov, N. V., \& Gorsky, P. V. (1934). Investigation of merchantable volume structure of standing pine and spruce forests. Moscow-Leningrad: Goslestehizdat, 184 p. [In Russian].

50. Tretyakov, N. V., Gorsky, P. V., \& Samoylovich, T. T. (1965). Foresters reference book. Tables for forest mensuration. Moscow: Lesnaya promyshlennost, 459 p. [In Russian].

51. Tsurik, Ye. I. (2000). Enumerations in forest mensuration: Textbook. Lviv: UNFU, 260 p. [In Ukrainian].

52. Tsurik, Ye. I. (2001). Measurement features and structure of forests. Lviv: UNFU, 362 p. [In Ukrainian].

53. Tyabera, A. P. (1981). Modelling the assortment and sort structure of the forests. Lesnoe hozyaystvo, 12, 39-43. [In Russian].

54. Wholesale prices for forest products (including firewood). (1988). Price list № 07-03. Moscow: Preyskurantizdat, 62 p. [In Russian].

55. Yield tables. (1958). Yield tables and tables of merchantable volume structure of main tree species of Ukraine. Kyiv: Derzhsilgospvidav URSR, 55 p. [In Ukrainian].

56. Zaharov, V. K. (1957). Methods of industrial estimation of stock volume wood assortment structure of standing forests. MoscowLeningrad: Goslesbumizdat, 96 p. [In Russian].

P. H. Khomiuk, L. S. Osadchuk, S. V. Portakh

Ukrainian National Forestry University, Lviv, Ukraine

\section{HISTORY OF DEVELOPMENT AND FEATURES OF IMPLEMENTATION OF STANDARDS ON MENSURATION OF FOREST MERCHANTABLE WOOD VOLUME AND PROCURED ROUND TIMBER}

The indicators of merchantable volume structure of the forest stock are taken into account when determining the amount of rental payment as the main part of forest profit, reasoning the age of main wood cutting, choosing the main tree species, determining the efficiency of forest management activities, during economic calculations for the assessment of the efficiency of forestry, assessment the rationality of getting different wood products from tree trunks, planning timber supplies from stockpiles to consumers, preparation of wood production balances, and in a number of other tasks. The main approaches of the characterization of wood stock by size and quality categories that functioned at different times on the territory of modern Ukraine from the beginning of 20 th century till nowadays are described in the paper. Analysis of forest management instructions, state standards and works of scientists performed on the basis of field researches of merchantable volume structure of the forest stocks, allows us to conclude that the use the classes of goodness, quality and merchantability of forest stands was the most significant factor. Innovations in the classification of timber by size and quality during the transition to new, harmonized with European standards for classification and accounting of merchantable round timber are analyzed. Among the basic are as follows: an increment of the part of merchantable wood in total stock by reducing the requirements for wood quality to the wood products; growth the volumes of timber used for technological processing; introduction of four quality classes for merchantable wood and separation of the firewood for industrial and nonindustrial use; increasing the number of dimensional categories of the classification of timber (seven classes of diameter instead of three); the transition from the use of the under-bark diameter of the log in the upper cut to determine the volume of timber to the middle over- or under-bark diameter; the abandonment of the industrial purpose during the classification of wood assortments in favour of size and quality criteria in accordance with the needs of the consumer market. The development of standards for assessing the merchantable volume structure of forests and standards for classification and accounting of merchantable round timber are presented in the paper. The main regulatory documents used in the practice of forestry for timber stock classification are listed as well.

Keywords: assortment stock structure; wood size category; category of technical suitability; quality class; state standard. 